\title{
Pengembangan Buku Ajar Metode Numerik Berbasis Pembelajaran Kolaboratif
}

\author{
Ni Kadek Rini Purwatii ${ }^{*}$, dan Ni Ketut Erawati ${ }^{2}$ \\ Jurusan Pendidikan Matematika, IKIP PGRI Bali \\ Jalan Seroja Tonja Denpasar Utara, Indonesia \\ 1*rinirie@gmail.com;2erawati_niketut@yahoo.com
}

Artikel diterima: 15-07-2020, direvisi: 07-01-2021, diterbitkan: 31-01-2021

\begin{abstract}
Abstrak
Buku ajar metode numerik haruslah memuat gambaran lengkap materi dan lebih menekankan pada implementasi metode, sehingga dapat menciptakan pembelajaran yang aktif dan interaktif. Penerapan pembelajaran kolaboratif yang diintegrasikan melalui buku ajar metode numerik akan menciptakan suasana pembelajaran yang mendorong mahasiswa untuk saling berinteraksi, bekerjasama, berbagi peran, tugas, dan tanggung jawab dalam menyelesaikan tugas atau masalah. Tujuan penelitian ini adalah untuk mengembangkan buku ajar metode numerik berbasis pembelajaran kolaboratif yang valid, praktis, dan efektif. Penelitian ini merupakan penelitian pengembangan Model Plomp yang terdiri dari tiga fase, yakni fase penelitian awal, fase membuat prototipe, dan fase penilaian dimana pada fase ini dilakukan uji validitas berdasarkan lembar validasi, kepraktisan berdasarkan angket respon dan keefektifan berdasarkan lembar observasi dan tes. Subjek penelitian adalah mahasiswa program studi pendidikan matematika IKIP PGRI Bali. Hasil yang diperoleh adalah buku yang dikembangkan layak digunakan, kepraktisan tergolong baik dan buku ajar metode numerik efektif digunakan dalam perkuliahan.

Kata Kunci: Buku Ajar, Pembelajaran Kolaboratif, Penelitian Pengembangan
\end{abstract}

\section{Development of Numerical Methods Textbook Based on Collaborative Learning}

\begin{abstract}
Numerical method textbooks must contain a complete description of the material and put more emphasis on the implementation of the method, to create active and interactive learning. The application of collaborative learning that is integrated through numerical methods textbooks will create a learning atmosphere that encourages students to interact, collaborate, share roles, assignments, and responsibilities in solving assignments or problems. The purpose of this research is to develop a valid, practical, and effective numerical method textbook based on collaborative learning. This research is research on the development of the Plomp Model which consists of three phases, namely the preliminary research phase, the prototyping phase, and the assessment phase wherein this phase the validity test is carried out based on the validation sheet, the practicality is based on the response questionnaire and the effectiveness is based on the observation sheet and the test. The research subjects were students of the mathematics education study program at the IKIP PGRI Bali. The results obtained are that the book developed is suitable for use, the practicality is good and the numerical method textbook is effectively used in lectures.

Keywords: Collaborative Learning, Development Research, Textbook.
\end{abstract}




\section{Pendahuluan}

Buku yang disusun dengan baik akan menjadi sumber ilmu dan memberikan pemahaman yang tepat bagi pembaca. Buku adalah salah satu bahan ajar yang dapat mendukung kegiatan pembelajaran, dimana desain dari bahan ajar menentukan interaksi diantara komponen pembelajaran (Parta, 2011).

Buku sebagai bahan ajar dapat menciptakan pembelajaran yang baik dan efektif. Pembelajaran baik dan efektif adalah pembelajaran yang aktif, interaktif, kreatif, edukatif, dan menyenangkan yang mengandung serangkaian kegiatan yang menjadi pedoman pencapaian tujuan pembelajaran. Salah satu pembelajaran aktif dan interaktif adalah pembelajaran kolaboratif.

Pembelajaran kolaboratif didasarkan pada tiga teori, yakni: teori konstruktivisme sosial, teori kognitif, dan teori motivasi (Hamid, 2011). Teori konstruktivisme sosial yang dipelopori oleh Vygotsky memandang bahwa belajar adalah sebuah pengalaman sosial yang diaktifkan melalui zona pengembangan proksimal, dimana tingkat perkembangan potensial akan meningkat apabila individu bekerja secara kolaboratif dengan teman sebaya yang lebih cakap. Teori kognitif menyatakan bahwa pertukaran konsep yang terjadi antar individu dalam kelompok mengakibatkan terjadinya transformasi ilmu pengetahuan pada setiap anggota dalam kelompok dan mendorong terjadinya pembelajaran aktif. Selanjutnya, teori motivasi menyatakan bahwa struktur pembelajaran kolaboratif menciptakan situasi yang kondusif untuk belajar serta mendorong setiap individu untuk saling berinteraksi dan belajar bersama untuk meningkatkan pemahaman masing-masing.

Pembelajaran kolaboratif adalah pembelajaran yang mendorong peserta didik untuk saling berinteraksi, bekerjasama, berbagi peran, tugas, dan tanggung jawab dalam menyelesaikan tugas atau masalah (Laal, 2012).

Pembelajaran kolaboratif memiliki lima elemen penting, yakni adanya ketergantungan positif, adanya interaksi, pertanggungjawaban individu dan kelompok, keterampilan interpersonal, proses kelompok (Laal, 2013). Agar lima elemen ini dapat tercipta maka diperlukan suatu aktivitas pembelajaran yang tepat dengan didukung bahan ajar yang tepat. Seperti dinyatakan oleh Akella (2012), pembelajaran kolaboratif berfokus pada pengembangan aktivitas dan kinerja yang bermakna. Sulaiman (2015) juga menyatakan bahwa pembelajaran matematika dapat dirancang dalam suatu aktivitas yang melibatkan kolaborasi melalui aktivitas kelompok dengan materi matematika yang dipilih dalam silabus. Aktivitas dan kinerja bermakna dapat tercipta melalui kolaborasi yang terjadi dalam aktivitas kelompok dalam menyelesaikan suatu topik permasalahan dari suatu materi matematika.

Untuk itu, aktivitas dan kinerja dalam pembelajaran kolaboratif perlu didukung 
oleh bahan ajar yang tepat. Seperti dinyatakan dalam penelitian Sunismi (2017) bahwa agar pelaksanaan pembelajaran kolaboratif dapat terealisasi dengan baik diperlukan bahan ajar yang mudah dipelajari. Salah satu bahan ajar yang dapat digunakan adalah buku ajar. Buku ajar perlu dirancang dengan tepat agar dapat mendorong terciptanya lima elemen dasar dari pembelajaran kolaboratif. Seperti dinyatakan dalam Khaidir (2016) bahwa buku ajar adalah bahan ajar yang dirancang dengan baik sesuai dengan prinsip-prinsip instruksional untuk mencapai tujuan pembelajaran suatu mata kuliah. Selain memaparkan materi, buku ajar juga dapat memotivasi mahasiswa untuk belajar, memberikan latihan, menyediakan rangkuman, dan menjelaskan capaian pembelajaran. Buku ajar memberikan kontribusi besar dalam meningkatkan kualitas pembelajaran dan pengembangan wawasan guru maupun peserta didik (UNESCO, 2014).

Pembelajaran kolaboratif ini akan sangat berguna dalam penyampaian materi perkuliahan yang memerlukan adanya kolaborasi antar peserta didik maupun peserta didik dengan dosen. Salah satunya adalah materi perkuliahan metode numerik. Mata kuliah metode numerik ini merupakan mata kuliah terapan yakni suatu mata kuliah yang membahas tentang penerapan dari konsep-konsep matematika sehingga diperlukan pemahaman materi yang mendalam. Penelitian Rikayanti (2018), menyatakan bahwa pemahaman akan suatu materi akan mendalam jika diiringi dengan kemampuan dalam memaknainya, seperti halnya dalam literasi matematika sehingga dalam mengaplikasikan konsep-konsep akan menjadi efektif dan efisien. Tujuan dari perkuliahan metode numerik adalah untuk dapat memahami konsep teoritis metode numerik dan penggunaanya dalam menyelesaikan permasalahan, serta untuk dapat menerapkan pemikiran logis, kritis, dan sistematis dalam menganalisis permasalahan dan memilih metode yang efektif dan efisien.

Penerapan pembelajaran kolaboratif yang diintegrasikan melalui buku ajar metode numerik dapat menjadi salah satu alternatif dalam penyampaian materi perkuliahan. Pembelajaran kolaboratif akan menciptakan suasana pembelajaran yang mendorong mahasiswa untuk saling berinteraksi, bekerjasama, berbagi peran, tugas, dan tanggung jawab dalam menyelesaikan tugas atau masalah. Untuk mendukung terciptanya suasana tersebut, buku ajar metode numerik haruslah memuat gambaran lengkap materi metode numerik dan lebih menekankan pada implementasi metode dalam permasalahan matematis, sehingga menuntut mahasiswa untuk melakukan analisis permasalahan. Tentunya dalam menganalisis permasalahan ini diperlukan kolaborasi antar mahasiswa maupun dosen. Penerapan pembelajaran kolaboratif pada mata kulaih metode numerik telah terbukti mendapat respon yang baik dari 
mahasiswa. Hal ini sesuai dengan penelitian Purwati (2017) dimana persepsi kualitas pengajaran mata kuliah metode numerik yang menerapkan model pembelajaran kolaboratif termasuk dalam kriteria sangat baik.

Untuk mendukung terlaksananya pembelajaran kolaboratif ini maka diperlukan suatu penunjang pembelajaran, yakni buku ajar metode numerik. Buku ajar ini haruslah lebih menekankan pada implementasi metode, sehingga buku ajar ini dapat mendorong mahasiswa untuk berkolaborasi dengan rekannya maupun dosen. Berdasarkan penjabaran tersebut, maka perlu untuk dilakukan pengembangan buku ajar metode numerik berbasis pembelajaran kolaboratif. Penelitian pengembangan ini dilakukan untuk mengetahui proses pengembangan buku ajar metode numerik berbasis pembelajaran kolaboratif, serta untuk mengetahui validitas, kepraktisan, dan kefektifan buku ajar metode numerik berbasis pembelajaran kolaboratif.

\section{Metode}

Jenis penelitian yang dilaksanakan adalah penelitian pengembangan sesuai model pengembangan Plomp. Dalam Nieveen (2013, p.19) dinyatakan bahwa model pengembangan Plomp terdiri dari tiga fase, yakni: (1) Fase penelitian awal (preliminary research) yang meliputi analisis kebutuhan dan konteks, pengkajian teori dan literatur, serta melakukan pengembangan kerangka konseptual; (2)
Fase membuat prototipe (prototyping phase) yang meliputi perancangan dan pengembangan. Pengembangan prototipe dilakukan melalui evaluasi formatif, yakni untuk merevisi buku ajar yang sedang dikembangkan dengan cara validasi oleh ahli/validator. Validasi dan revisi prototipe dilakukan berulang kali; (3) Fase penilaian (assessment phase) yang meliputi penilaian untuk menentukan kelayakan, menganalisis kepraktisan dan keefektifan buku ajar berdasarkan hasil uji coba.

Instrumen yang digunakan untuk memperoleh data mengenai kelayakan/validitas adalah lembar validitas dengan kategori kevalidan ditentukan berdasarkan kriteria berikut:

Tabel 1.

Kriteria Validitas

\begin{tabular}{ll}
\hline \multicolumn{1}{c}{ Kategori } & Kriteria \\
\hline Sangat Valid & $4 \leq \bar{V}_{r} \leq 5$ \\
\hline Valid & $3 \leq \bar{V}_{r}<4$ \\
\hline Kurang Valid & $2 \leq \bar{V}_{r}<3$ \\
\hline Tidak Valid & $1 \leq \bar{V}_{r}<2$ \\
\hline
\end{tabular}

(Sumber: Dhany, 2013)

Analisis kepraktisan dilakukan berdasarkan data angket respon mahasiswa (Bintiningtyas, 2016; Rusnilawati, 2016). Hasil dari angket respon dikategorikan sebagai berikut:

Tabel 2.

Pedoman Pengkategorian Kepraktisan

\begin{tabular}{lc|}
\hline \multicolumn{1}{c}{ Kategori } & Kriteria Kecenderungan \\
\hline Sangat Baik & $X \geq M+1,8 S D=X \geq 101$ \\
\hline Baik & $M+0,6 S D \leq X<M+1,8 S D=82 \leq X$ \\
& $<101$ \\
\hline Cukup Baik & $\begin{array}{c}M-0,6 S D \leq X<M+0,6 S D=62 \leq X \\
<82\end{array}$ \\
\hline Kurang Baik & $\begin{array}{c}M-1,8 S D \leq X<M-0,6 S D=43 \leq X \\
\end{array}$ \\
\hline $\begin{array}{l}\text { Sangat Kurang } \\
\text { Baik }\end{array}$ & $X<2$ \\
\hline
\end{tabular}

Mosharafa: Jurnal Pendidikan Matematika Volume 10, Nomor 1, Januari 2021 Copyright $\odot 2021$ Mosharafa: Jurnal Pendidikan Matematika 
(Sumber: Rusnilawati, 2016)

Selanjutnya, analisis keefektifan dilakukan berdasarkan hasil tes dan lembar observasi aktivitas perkuliahan. Kriteria hasil tes dikategorikan pada Tabel 3 dan kriteria hasil observasi aktivitas belajar dikategorikan pada Tabel 4.

Tabel 3.

Kriteria Hasil Belajar

\begin{tabular}{|cc|}
\hline \multicolumn{1}{c}{ Skor } & Kategori \\
\hline $85 \leq \bar{X} \leq 100$ & Sangat Baik \\
\hline $70 \leq \bar{X} \leq 84$ & Baik \\
\hline $55 \leq \bar{X} \leq 69$ & Cukup Baik \\
\hline $40 \leq \bar{X} \leq 54$ & Kurang Baik \\
\hline $0 \leq \bar{X} \leq 39$ & Sangat Kurang \\
\hline
\end{tabular}

Tabel 4.

Kriteria Observasi Aktivitas Belajar

\begin{tabular}{lc}
\hline Kategori & Kriteria Kecenderungan \\
\hline Sangat Baik & $X \geq M+1.8 S D$ \\
\hline Baik & $M+0.6 S D \leq X<M+1.8 S D$ \\
\hline Cukup & $M-0.6 S D \leq X<M+0.6 S D$ \\
\hline Kurang Baik & $M-1.8 S D \leq X<M-0.6 S D$ \\
\hline Sangat Kurang Baik & $X<M-1.8 S D$
\end{tabular}

Subjek dalam penelitian ini adalah mahasiswa semester VI program studi pendidikan matematika IKIP PGRI Bali. Penerapan pembelajaran kolaboratif yang diintegrasikan melalui buku ajar metode numerik didasarkan pada lima elemen penting pembelajaran kolaboratif, yakni adanya ketergantungan positif, adanya interaksi, pertanggungjawaban individu dan kelompok, keterampilan interpersonal, proses kelompok.

\section{Hasil dan Pembahasan}

\section{A. Fase Penelitian Awal (Preliminary Research)}

Penekanan pada fase penelitian awal (preliminary research) adalah pada validitas konten, tidak banyak pada konsistensi dan kepraktisan. Kegiatan yang dilakukan peneliti pada fase penelitian awal ini adalah analisis kebutuhan dan konteks, pengkajian literatur, dan pengembangan kerangka konseptual. Analisis situasi dan konteks dilakukan dengan meninjau proses pembelajaran yang dilaksanakan di kelas, mengidentifikasi kendala yang dialami selama pembelajaran, meninjau perangkat pembelajaran yang digunakan meliputi silabus, RPS, bahan ajar, serta menganalisis kemampuan peserta didik. Selain melakukan analisis situasi dan konteks di kelas, dalam fase ini juga dilakukan studi pustaka dan meninjau contoh-contoh buku ajar maupun buku refrensi yang relevan sebagai bahan pertimbangan dalam membuat buku ajar metode numerik.

Berdasarkan hasil analisis kebutuhan dan konteks pada fase penelitian awal diperoleh beberapa informasi terkait adanya beberapa kendala dalam perkuliahan metode numerik dimana konsep metode numerik yang cukup kompleks mengakibatkan peserta didik kerap mengalami kebingungan dalam menerapkan metode. Hal ini juga disebabkan karena materi perkuliahan metode numerik cenderung masih dalam tahap pengenalan metode dan teori-teori yang mendasarinya sehingga peserta didik kurang memahami implementasi dan aplikasi dari metode numerik. Selain itu, kolaborasi antar mahasiswa maupun dosen dalam perkuliahan metode numerik masih kurang terjalin, sehingga penyampaian dan 
pemahaman materi kurang optimal. Pada perkuliahan, dosen umumnya membagi mahasiswa dalam beberapa kelompok dan membagikan materi untuk dipresentasikan. Kurang jelasnya cakupan materi yang diberikan kerap mengakibatkan mahasiswa menyajikan materi terlalu luas diluar pemahamannya sendiri dan justru mengabaikan konsep dasar dari metode numerik itu sendiri. Penggunaan buku refrensi dalam perkuliahan juga menjadi salah satu kendala dimana buku refrensi yang digunakan memiliki cakupan materi yang luas dan cukup sulit dipahami baik dari segi bahasa maupun kajian matematisnya. Beberapa buku metode numerik yang dikaji diantaranya adalah Buku Pengantar Metode Numerik dari Penerbit ANDI yang ditulis oleh Agus Setiawan, dan Introductory Methods of Numerical Analysis yang ditulis oleh Sastry, S.S. Kedua buku ini memiliki karakteristik yang berbeda. Buku karya Agus Setiawan lebih menekankan pada aplikasi metode numerik di bidang teknik sipil dengan kajian matematis yang cukup rumit. Buku karya Sastry menyajikan beragam contoh latihan soal dengan lagkah-langkah penyelesaiannya. Seperti halnya dengan buku karya Agus Setiawan, buku ini pun menyajikan kajian matematis yang cukup rumit.

Selanjutnya, pengkajian literatur dan pengembangan kerangka konseptual menghasilkan informasi terkait capaian pembelajaran mata kuliah metode numerik yang kemudian diturunkan menjadi sub capaian pembelajaran. Capaian pembelajaran mata kuliah metode numerik, yaitu: (1) mahasiswa mampu menguasai konsep teoritis matematika terkait materi metode numerik; (2) mahasiswa mampu menerapkan pemikiran logis, kritis, dan sistematis dalam memahami konsep teoritis metode numerik dan penggunaanya dalam menyelesaikan permasalahan matematika; (3) mahasiswa mampu menunjukkan kinerja mandiri dan rasa tanggung jawab dalam menerapkan konsep teoritis metode numerik dalam menyelesaikan soal.

\section{B. Fase Membuat Prototipe (Prototyping Phase)}

Penekanan pada fase membuat prototipe (prototyping phase) adalah konsistensi (membangun validitas) dan kepraktisan. Kemudian, secara bertahap memperhatikan efektivitas. Kegiatan yang dilakukan peneliti pada fase membuat prototipe meliputi perancangan dan pengembangan. Pada tahap perancangan dilakukan penyusunan prototipe buku ajar. Penyusunan buku ajar diawali dengan menganalisis materi yang akan disusun dalam buku ajar. Berdasarkan hasil kajian terhadap beberapa buku refrensi, maka dikembangkan suatu buku ajar metode numerik yang menyajikan kajian matematis lebih sederhana dari buku-buku metode numerik pada umumnya, serta menekankan pada implementasi metode yang diwujudkan melalui penyajian beragam contoh dan latihan soal. Langkah- 
langkah penyelesaian contoh soal disusun secara sistematis dan rinci.

Selanjutnya dilakukan penyusunan sesuai dengan komponen-komponen buku ajar, yaitu bagian pembuka, isi, dan penutup yang disajikan pada Gambar 1, Gambar 2, dan Gambar 3. Hasil penyusunan buku ajar pada tahap perancangan ini disebut sebagai prototipe 1.

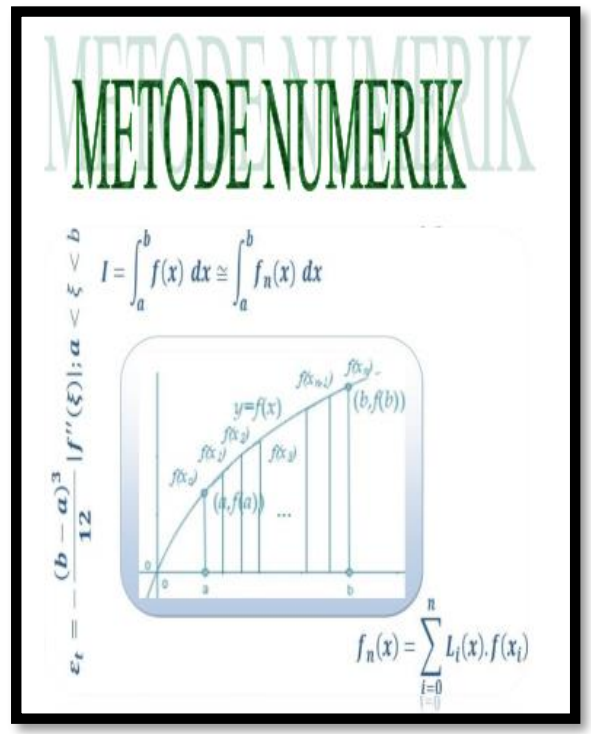

Gambar 1. Sampul Buku

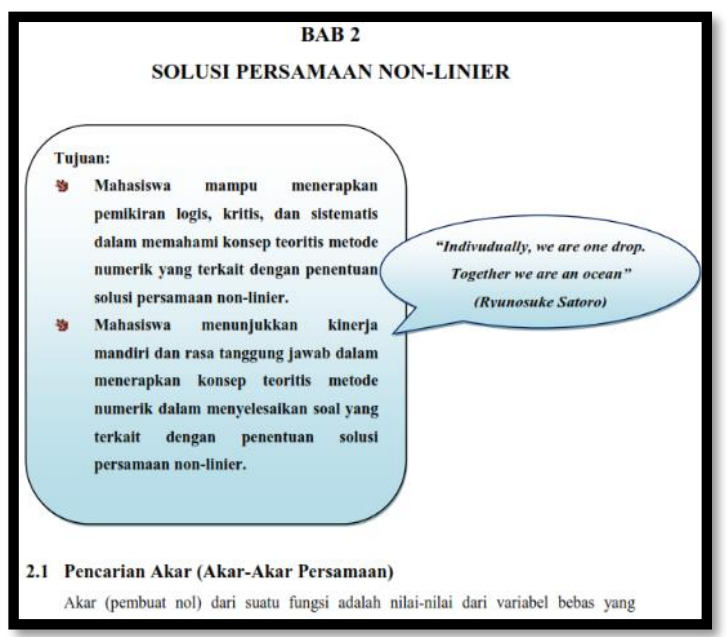

Gambar 2. Bagian Isi
DAFTAR PUSTAKA

Dalziel, Stuart. 1998. Numerical Methods. Department of Applied Mathematics and Theoretical Physics University of Cambridge. Diakses pada http://www.damtp.cam.ac.uk/user/fdl/people/sd103/lectures

Irwanto. 2012. Deret Taylor dan Analisis Galat. Yogyakarta: Fakultas Sains dan Teknologi Jurusan Teknik Informatika Universitas Teknologi Yogyakarta.

Kaw, Autar. 2011. Textbook Notes of Introduction to Numerical Methods. Diakses pada http://numericalmethods.eng. usf.edu.

Larson, Ron., David C. Falvo. 2009. Elementary Linear Algebra. Boston: Houghton

Gambar 3. Bagian Penutup

Bagian pembuka buku ajar terdiri dari sampul buku, kata pengantar, daftar isi, dan pendahuluan. Pada bagian pendahuluan buku ajar dibahas mengenai kegunaan metode numerik dan prinsip yang mendasarinya. Sampul buku ajar metode numerik seperti disajikan pada Gambar 1. Bagian isi buku ajar terdiri dari judul bab, tujuan, judul subbab, contoh soal, rangkuman, dan soal latihan. Terdapat 6 bab dalam buku ajar ini, yakni bab 1 tentang galat, bab 2 tentang solusi sistem persamaan non-linier, bab 3 tentang solusi sistem persamaan linier, bab 4 tentang interpolasi polinomial, bab 5 tentang integrasi numerik, dan bab 6 tentang solusi persamaan diferensial biasa. Ilustrasi grafik dalam buku ajar dibuat dengan bantuan software Geogebra, sedangkan iterasi pada setiap metode dilakukan dengan bantuan program Microsoft Excel. Pada setiap bab disajikan tujuan pembelajaran dan katakata motivasi yang dikutip dari berbagai sumber, sehingga diharapkan dapat memotivasi mahasiswa untuk berkolaborasi dengan rekannya dalam memahami suatu permasalahan. Penerapan pembelajaran kolaboratif yang diintegrasikan melalui buku ajar metode 
numerik ini dilakukan dengan langkahlangkah berikut:

1. Peserta didik dalam kelompok menetapkan tujuan belajar dan membagi tugas sendiri-sendiri;

2. Peserta didik dalam kelompok membaca, berdiskusi, dan menulis;

3. Peserta didik dalam kelompok mengkaji materi dan permasalahan buku ajar;

4. Setelah kelompok kolaboratif menyepakati hasil pemecahan masalah, masing-masing peserta didik menulis hasil pemecahan masalah;

5. Dosen menunjuk salah satu peserta didik dari salah satu kelompok secara acak (selanjutnya diupayakan agar semua peserta didik dalam setiap kelompok mendapat giliran) untuk melakukan presentasi. Peserta didik pada kelompok lain mengamati, mencermati, membandingkan hasil presentasi tersebut, dan menanggapi;

6. Masing-masing peserta didik dalam kelompok kolaboratif melakukan revisi (bila diperlukan) terhadap hasil pemecahan masalah yang telah ditulis dan menyusun suatu simpulan;

7. Simpulan yang telah disusun perkelompok kolaboratif dikumpulkan kemudian dikoreksi, dikomentari, dinilai, dikembalikan, dan didiskusikan.

Bagian isi buku ajar metode numerik seperti disajikan pada Gambar 2. Bagian penutup buku ajar terdiri dari daftar pustaka seperti disajikan pada Gambar 3.

Pada tahap pengembangan dilakukan pengembangan prototipe melalui evaluasi formatif yang bertujuan untuk merevisi buku ajar yang sedang dikembangkan dengan cara validasi oleh ahli/validator. Validasi dan revisi prototipe terjadi berulang kali untuk memastikan buku ajar benar-benar valid sebelum diujicobakan.

Uji validitas pada prototipe 1 dilakukan oleh tiga orang ahli/validator dengan mengisi lembar validasi. Lembar validasi yang disusun digunakan untuk mengukur kelayakan komponen buku ajar yang meliputi komponen kelayakan isi, komponen kelayakan kebahasaan, dan komponen kelayakan penyajian. Validator 1 dan 3 menyatakan bahwa buku ajar layak digunakan dengan sedikit revisi, sedangkan validator 2 menyatakan bahwa buku ajar layak digunakan tanpa revisi. Hasil validasi prototipe 1 disajikan pada Tabel 5 yang menunjukkan bahwa rata-rata tiap komponen buku ajar termasuk kriteria sangat valid.

Tabel 5.

Hasil Validasi Buku Ajar Metode Numerik

\begin{tabular}{|llcl}
\hline No & Aspek Penilaian & $\begin{array}{l}\text { Rata-Rata } \\
\text { Tiap } \\
\text { Komponen }\end{array}$ & Kriteria \\
\hline 1 & $\begin{array}{l}\text { Komponen } \\
\text { Kelayakan Isi }\end{array}$ & 4,46 & $\begin{array}{l}\text { Sangat } \\
\text { Valid }\end{array}$ \\
\hline 2 & $\begin{array}{l}\text { Komponen } \\
\text { Kelayakan } \\
\text { Kebahasaan }\end{array}$ & 4,57 & $\begin{array}{l}\text { Sangat } \\
\text { Valid }\end{array}$ \\
\hline 3 & $\begin{array}{l}\text { Komponen } \\
\text { Kelayakan } \\
\text { Penyajian }\end{array}$ & 4,19 & $\begin{array}{l}\text { Sangat } \\
\text { Valid }\end{array}$ \\
\hline 4 & $\begin{array}{l}\text { Rata-rata Total } \\
\text { Validator }\end{array}$ & 4,41 & Sangat \\
Valid
\end{tabular}

Beberapa saran yang diberikan validator yang dapat dijadikan pedoman dalam revisi prototipe 1, yakni: (1) Buku ajar metode 
numerik memiliki isi yang padat dan lengkap dengan penyajian yang baik, akan tetapi untuk mendorong minat mahasiswa dalam mendalami dan mempelajari lebih lanjut tentang materi metode numerik sekiranya dapat ditambahkan penerapan dan implementasi setiap sub materi dalam kehidupan nyata baik disisipkan dalam pendahuluan, materi maupun soal; (2) Setiap definisi, rumus, gambar diambil dari sumber lain agar menyertakan refrensinya.

Hasil uji validasi ini kemudian menjadi pedoman dalam melakukan revisi pada prototipe 1 sehingga diperoleh buku ajar dalam bentuk prototipe 2 yang valid dan siap diujicobakan. Uji coba pertama yang dilakukan pada prototipe 2 adalah uji coba terbatas. Dalam uji coba terbatas, buku ajar diuji cobakan pada mahasiswa semester VIC. Fokus dari uji coba ini adalah untuk mendapatkan gambaran perkuliahan dengan menggunakan buku ajar metode numerik dan kepraktisan dari buku ajar. Pada uji coba ini, mahasiswa diberikan angket respon dan dilakukan pengamatan terhadap aktivitas perkuliahan. Berdasarkan hasil penelitian diperoleh aktivitas perkuliahan metode numerik menggunakan buku ajar berjalan baik.

Kepraktisan buku ajar didasarkan pada penilaian mahasiswa. Berdasarkan hasil analisis diperoleh total rata-rata sebesar 83,70 yang menurut pedoman pengkategorian pada Tabel 2 dapat dinyatakan bahwa kepraktisan buku ajar tergolong baik. Selain itu, diperoleh hasil bahwa secara keseluruhan buku ajar metode numerik mendapat respon yang baik dari mahasiswa, meskipun terdapat beberapa aspek dari buku ajar yang masih dalam kriteria cukup dan kurang baik. Untuk itu perlu dilakukan revisi pada buku ajar sesuai dengan saran dan kritik yang diberikan oleh mahasiswa. Adapun beberapa pendapat, saran dan kritik dari mahasiswa terkait buku ajar metode numerik, yakni: (1) Kualitas buku sangat baik dan membantu dalam memahami materi serta menyelesaikan tugas yang diberikan dosen; (2) Sistematika penulisan sudah jelas baik dari ukuran huruf, spasi, jenis maupun rumus tiap bab dan subbabnya; (3) Isi buku sangat jelas, materinya runtun dari bab ke bab, langkahlangkah penyelesaian soalnya sangat jelas; (4) Dalam menganalisis iterasi yang disajikan dalam tabel, rumus susah untuk dipahami contohnya dalam menentukan galat atau nilai pada variabel yang lain; (5) Lebih bagus dan sangat jelas bila dalam buku dicantumkan juga cara mencari dengan menggunakan bantuan aplikasi Microsoft Excel agar pembaca tidak bingung dengan nilai yang muncul begitu banyak dalam tabel. Hasil analisis dari angket respon serta saran dan kritik yang diperoleh pada tahap ini dijadikan pedoman dalam merevisi prototipe 2 sehingga terbentuklah prototipe 3 .

\section{Fase Penilaian (Assessment Phase)}

Penekanan pada fase penilaian (assessment phase) adalah kepraktisan dan efektivitas. Kegiatan yang peneliti lakukan pada fase penilaian adalah melakukan 
penilaian untuk menganalisis kepraktisan dan keefektifan buku ajar berdasarkan hasil uji coba. Pada fase ini dilakukan uji coba lapangan pada prototipe 3 yang melibatkan mahasiswa semester VIA dan VIB. Pada uji coba ini dilakukan pengamatan terhadap aktivitas perkuliahan, pemberian tes dan angket respon. Hasil yang diperoleh pada uji coba ini digunakan sebagai pedoman merevisi prototipe 3 , sehingga diperoleh produk final yang praktis dan efektif.

Kepraktisan buku ajar diukur dengan memberikan angket respon kepada mahasiswa. Angket respon ini terdiri dari 7 aspek, yakni aspek kesesuaian dengan silabus/kurikulum, aspek kepaduan materi, aspek kepadatan materi, aspek tingkat kesulitan, aspek aplikasi, aspek kerapian penulisan, dan aspek refrensi yang digunakan. Hasil analisis data angket respon menunjukkan bahwa buku ajar metode numerik mendapat respon yang baik dari peserta didik baik dari aspek kesesuaian dengan silabus/kurikulum, aspek kepaduan materi, aspek tingkat kesulitan, aspek aplikasi, aspek kerapian penulisan, dan aspek refrensi yang digunakan. Meskipun dari aspek kepadatan materi mendapat respon cukup baik, tetapi secara keseluruahan buku ajar ini mendapat respon yang baik. Berdasarkan hasil analisis data diperoleh total rata-rata respon mahasiswa sebesar 88,12 yang menurut pedoman pengkategorian pada Tabel 2 dapat dinyatakan bahwa kepraktisan buku ajar tergolong baik.
Uji keefektifan buku ajar dilakukan dengan melakukan pengamatan pada aktivitas perkuliahan dan pemberian tes. Tes yang diberikan mencakup aspek pemahaman konsep, analisis, dan pemecahan masalah. Berdasarkan hasil analisis data diperoleh bahwa rata-rata skor hasil belajar adalah 70,58 yang termasuk dalam kategori baik. Data juga menunjukkan bahwa sebesar 79,07\% mahasiswa memperoleh nilai B dalam perkuliahan metode numerik yang menggunakan buku ajar metode numerik sebagai bahan ajar pendukung perkuliahan.

Selanjutnya keefektifan buku ajar dapat dilihat dari keaktifan mahasiswa dalam perkuliahan. Untuk itu digunakan lembar observasi aktivitas mahasiswa. Hasil analisis data menunjukkan bahwa kualitas keaktifan mahasiswa semester VIA maupun VIB dalam perkuliahan metode numerik tergolong baik. Berdasarkan penjabaran data hasil belajar dan keaktifan mahasiswa dalam perkuliahan metode numerik menunjukkan buku ajar metode numerik efektif digunakan dalam pembelajaran.

Berdasarkan hasil penelitian, maka secara umum pada kegiatan uji coba terbatas dan uji coba lapangan diperoleh bahwa buku ajar yag dikembangkan sudah memenuhi kriteria valid, praktis, dan efektif. Buku ajar yang dikembangkan dapat tergolong valid karena buku ajar telah sesuai dengan capaian pembelajaran, memiliki komponen yang sesuai sebagai suatu buku ajar. Buku ajar yang dikembangkan tergolong praktis karena 
memberikan manfaat kepada guru dan juga peserta didik. Beberapa manfaat yang diberikan buku ajar metode numerik dalam penerapan pembelajaran kolaboratif adalah membantu memahami materi dan menyelesaikan tugas, serta memahami implementasi dan aplikasi metode.

Aktivitas dan kinerja dalam pembelajaran kolaboratif perlu didukung oleh bahan ajar yang tepat. Bahan ajar merupakan bagian yang perlu disediakan (Nasution, 2017). Hal ini sejalan dengan pernyataan Prabawati (2019) bahwa salah satu komponen pembelajaran yang mendukung keberhasilan pembelajaran adalah bahan ajar. Sehingga, bahan ajar yang dikembangkan harus sesuai dengan kondisi, kebutuhan dan karakteristik peserta didik (Yulius, 2017).

\section{Penutup}

Buku ajar metode numerik dirancang agar mendorong mahasiswa berkolaborasi dengan rekannya maupun dosen. Kolaborasi yang baik akan menciptakan terjadinya interaksi dan kerja sama. Dalam implementasinya, buku ajar ini dijadikan bahan ajar pendukung pembelajaran kolaboratif. Buku ajar ini sangat tepat digunakan dalam pembelajaran kolaboratif maupun model pembelajaran lainnya sebagai bahan ajar pendukung.

\section{UCAPAN TERIMA KaSIH}

Terimakasih kepada DRPM Ristek Dikti yang telah mendanai penelitian ini melalui skema hibah Penelitian Dosen Pemula.
Kepada IKIP PGRI Bali, khususnya Jurusan Pendidikan Matematika yang mengijinkan dan mendukung pelaksanaan penelitian.

\section{Daftar Pustaka}

Akella, N. (2012). The Real Deal on Collaborative Learning. Education Journal, 2(3), 23-29.

Bintiningtiyas, Nita., Achmad Lutfi. (2016). Pengembangan Permainan Varmintz Chemistry sebagai Media Pembelajaran pada Materi Sistem Periodik Unsur. Unesa Journal of Chemical Education, 5(2), 135-141.

Hamid, M. S. (2011). Metode Edutainment. Yogyakarta: Diva Press.

Khaidir, C. (2016). Pengembangan Buku Ajar Metode Numerik Berbasis Konstruktivisme di IAIN Batusangkar. .Jurnal Ta'dib, 19(1), 67-82.

Laal, M., Mozhgan, L. (2012). Collaborative Learning: What is it? Procedia Social and Behavioral Sciences,31(2012), 491-495.

Laal, M., Loabat, G., Mahrokh, D. (2013). Individual accountability in collaborative learning. Procedia Social and Behavioral Sciences, 93(2013), 286-289.

Nasution, M. D., Elfrianto, N., Feri. H. (2017). Pengembangan Bahan Ajar Metode Numerik dengan Pendekatan Metakognitif Berbantuan Matlab. Mosharafa: Jurnal Pendidikan Matematika, 6(1), 69-80.

Nieveen, N., Tjeerd, P. (2013). Educational Design Research. Enchede: 
Netherlands Institute for curriculum development.

Parta, I. N. (2011). Developing Mathematics Teaching Material "Investigative" for Pre-Service Mathematics Teacher. Paper has been presented at International Seminar and the Fourth National Conference on Mathematics Education 2011 "Building the Nation Character through Humanistic Mathematics Education". Department of Mathematics Education, Yogyakarta State University, Yogyakarta, July 21232011.

Prabawati, M. N., Tatang, H., Turmudi. (2019). Pengembangan Lembar Kerja Siswa Berbasis Masalah dengan Strategi Heuristic untuk Meningkatkan Kemampuan Literasi Matematis. Mosharafa: Jurnal Pendidikan Matematika, 8(1), 37-48

Purwati, N. K. R. (2017). Persepsi Kualitas Pengajaran Mata Kuliah Metode Numerik. Jurnal Emasains, VI(1), 1117.

Rusnilawati, R. (2016). Pengembangan Perangkat Pembelajaran Matematika Bercirikan Active Knowledge Sharing dengan Pendekatan Saintifik Kelas VIII. Jurnal Riset Pendidikan Matematika,3(2), 245-258.

Sulaiman, N. D., Masitah, S. (2015). Engaging Collaborative Learning to Develop Students' Skills of the $21^{\text {st }}$ Century. Mediterranean Journal of Social Sciences, 6(4), 544-552.
Sunismi, A. H. F. (2017). Prototipe Model Collaborative Learning Matematika Melalui Media Blog dengan Interactive Digital Book Matakuliah Kalkulus II. Jurnal Fourier, 6(2), 69-83.

UNESCO. (2014). Textbooks and Learning Resources: Guidelines for Developers and Users.

Yulius, B., Irwan, Yerizon. (2017). Pengembangan Perangkat Pembelajaran Matematika Berbasis Model Pembelajaran Penemuan dengan Masalah Open Ended untuk Peserta Didik SMA Kelas X Semester 2. Mosharafa: Jurnal Pendidikan Matematika, 6(2), 279-286

\section{Riwayat Hidup PENULIS}

\section{Ni Kadek Rini Purwati, S.Si., M.Pd}

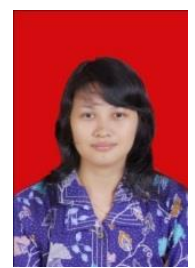

Lahir di Amlapura, 11 September 1987. Staf pengajar di Program Studi Pendidikan Matematika FKIP Unvesitas PGRI Mahadewa Indonesia (d/h IKIP PGRI Bali). Studi S1 Matematika, Universitas Udayana, Denpasar, lulus tahun 2009; S2 Pendidikan Matematika Universitas Pendidikan Ganesha, Singaraja, lulus tahun 2011.

\section{Ni Ketut Erawati, S.Si., M.Pd}

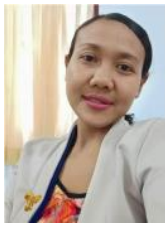

Lahir di Ketewel, 2 Agustus 1986. Staf pengajar di Program Studi Pendidikan Matematika FKIP Unvesitas PGRI Mahadewa Indonesia (d/h IKIP PGRI Bali). Studi S1 Matematika, Universitas Udayana, Denpasar, lulus tahun 2009; S2 Pendidikan Matematika Universitas Pendidikan Ganesha, Singaraja, lulus tahun 2015. 